sound at each inspiration. Deep exploration of one of the sores revealed the presence of a thin rubber ring, which had evidently been slipped over the head (probably by some children), and had gradually tightened, burying itself in the muscles of the neck and causing pressure on the trachea. The ring was exposed, snipped through, and withdrawn without any difficulty. The skin had united again over it, except in three or four places where the rubber had formed ulcerating sores. The accompanying figure shows the exact size of the rubber ring.

It was about three weeks after the removal of the ring before the breathing became normal again, any excitement bringing on the shrill whistling inspirations at once.

\title{
AN INTERESTING INSTANCE OF PROLIFERATION OF OVARIAN TISSUES.
}

\section{By Frederick HOBDAY, F.R.C.V.S., Kensington.}

THE subject, a female cat aged six months, having become a nuisance, was brought for oöphorectomy in September I900, and, having been anæsthetised with A.C.E. mixture, had the abdomen opened at the median line in the usual manner. Instead of ligaturing the horns and removing the ovaries, the former procedure was dispensed with, the horns being left intact and the ovaries thomselves separately snipped off with scissors. To all appearance in each case this was done completely, and the cat was sent home a week later, primary union of the abdominal wall having taken place.

Five months afterwards I received a message to say that she had had two kittens. As soon as they were weaned the abdomen was again opened in a fresh place, a little nearer the umbilicus than the previous operation wound, and upon exposing the uterus the ovaries were found to be quite twice as large as they had been on the previous occasion, and cystic. In fact there appeared to be very little solid substance in either of them. On this occasion the horns were carefully ligatured above and below each ovary, and the whole of the intervening tissue removed. The patient made an uneventful recovery, primary union of the abdominal wound again taking place.

The case is of interest because it shows that even if a very small portion of ovarian tissue is left pregnancy is possible, and it also shows to what an extent the ovaries may be injured without the destruction of their function and activity.

\section{GASTROTOMY ON A DOG}

By W. H. Chase, M.R.C.V.S., Tutor, Royal Veterinary College, London.

Subject.-A three-year-old collie bitch brought by the owner to the College Out-patients' Free Clinique on I Ith August I9O2.

History.-Two days previously some children, when playing with 